\title{
Civic Education on Stage: Civic Values and Virtues in the Jesuit Schools of the Polish-Lithuanian Commonwealth
}

\author{
Jolanta Rzegocka
}

The Jesuit order and its theater have played a vital part in the history of Europe and its cultural heritage. ${ }^{1}$ Ever since the founding of the Society in 1540 , the Jesuits have been active preachers, distinguished theologians and disputants, and have served as confessors and tutors to sovereigns and members of royal families across Christendom. ${ }^{2}$ However, it is the order's emphasis on education and the Jesuits' role as teachers that put the activities of the Society at the heart of the present chapter. Jesuit colleges modeled after their prominent school, the Collegium Romanum (1551), offered a combination of high-quality teaching based on the study of the classics and a new type of instruction promoting critical thinking, modern piety, eloquence, and drama skills. It was through exercises in rhetorical skills and drama that the civic virtues were taught to students of Jesuit colleges. This seems especially true in the case of Jesuit schools in the Polish-Lithuanian Commonwealth, as attested by plays

1 The chapter presents preliminary results from the research project "Civic Education in Jesuit School Theaters of the Polish-Lithuanian Commonwealth Playbills in the Jesuit Archives of Vilnius, Rome, and Selected Polish Libraries," funded by the National Science Center of Poland UMO-2014/13/B/HS2/o0524. The principal investigator is Prof. Jan Okoń, author of pioneering studies on Jesuit school theater and playbills. His seminal study is Dramat iteatr szkolny: Sceny jezuickie XVII wieku (Wrocław:Zakład Narodowy im. Ossolińskich, 1970). I am indebted to Prof. Okoń for his sharing ideas on Jesuit theatre season, for drawing my attention to the Lublin 1726 playbill, and for his continuous encouragement and critical comments on this chapter.

2 Stanisław Obirek, a historian of the Jesuit order in Poland-Lithuania, notes that Jesuits were advised to maintain political neutrality, and the 1565 General Congregation only allowed short periods of one or two-month stays at ducal and royal courts. During a 1576 interregnum in Poland, Superior General Everard Mercurian (1514-80) reminded the Polish Jesuits that they should stay politically neutral and abstain from preaching at parliamentary sessions and political assemblies of the Polish-Lithuanian nobility. Stanisław Obirek, Jezuici na dworach Batorego i Wazów 1580-1668: Wptyw kapelanów dworskich i wychowawców książat na postawy panujacych $i$ polityke państwa (Cracow: Wydział Filozoficzny Towarzystwa Jezusowego, 1996), 5-6. 
and playbills from the Polish and Lithuanian provinces of the Society. ${ }^{3}$ The interest of the Polish-Lithuanian Jesuits in history teaching and the production of school plays based on historical sources suggests they attempted to tune their model of education to the needs of a country which cherished classical republican ideas and whose political thinkers constantly discussed the nature and goals of political community, the arrangement of its political institutions, and the roles and duties of its citizens and rulers. ${ }^{4}$ As a closer analysis of playtexts and playbills shows, the Jesuit school theater of the PolishLithuanian province played a distinctive role in shaping models of virtuous citizenry in Poland-Lithuania in the seventeenth and eighteenth centuries. In Europe as a whole, there were two distinctive features of Jesuit school theater: its regularity, which created a "theater season," and the Jesuit insistence on teaching virtues in order to achieve docta et eloquens pietas (learned and eloquent piety). In the case of Poland-Lithuania, Jesuit theater also used an abundance of national themes in dramatic performances, while addressing questions of the republican political system as a respublica mixta-the mixed state which was the foundation of the Polish-Lithuanian Commonwealth. ${ }^{5}$ It is only by examining selected plays and playbills that the distinctiveness of the school theater of the Polish-Lithuanian province can be appreciated in full. ${ }^{6}$

3 Dramat staropolski od początków do powstania sceny narodowej: Bibliografia, vol. 2: Programy drukiem wydane do r. 1765, part 1: Programy teatru jezuickiego, ed. Władysław Korotaj et al. (Wrocław: Ossolineum, 1965). Playbills of the school theater of the Piarists, Theatines, and Basilian fathers are listed in Dramat staropolski od poczatków do powstania sceny narodowej: Bibliografia, vol. 2: Programy drukiem wydane do r. 1765, part 2: Programy teatru pijarskiego oraz innych zakonów i szkót katolickich, ed. Władysław Korotaj et al. (Wrocław: Ossolineum, 1978).

4 Dorota Pietrzyk-Reeves, Ład Rzeczypospolitej: Polska myśl polityczna XVI wieku a klasyczna tradycja republikańska (Cracow: Księgarnia Akademicka, 2012); Pietrzyk-Reeves, "O pojęciu Rzeczypospolita (res publica) w polskiej myśli politycznej Xvı wieku," Czasopismo prawnohistoryczne 1 (2010): 38-64; Anna Grześkowiak-Krwawicz, Regina libertas: Wolność w polskiej myśli politycznej XVIII wieku (Gdańsk: Słowo/Obraz Terytoria, 2006).

5 English-language studies on the Polish-Lithuanian Commonwealth include: Robert Frost, The Oxford History of Poland Lithuania, vol. 1: The Making of the Polish-Lithuanian Union, 1385-1569 (Oxford: Oxford University Press, 2015); Benedict Wagner-Rundell, Common Wealth, Common Good: The Politics of Virtue in Early Modern Poland-Lithuania (Oxford: Oxford University Press, 2015); Norman Davies, God's Playground: A History of Poland, vol. 1: The Origins to 1795, revised ed. (Oxford: Oxford University Press, 2005); Teresa Bałuk-Ulewiczowa, Goslicius' "Ideal Senator" and His Cultural Impact over the Centuries: Shakespearean Reflections (Warsaw: Polska Akademia Umiejętności, 2009).

6 Major studies on Polish-Lithuanian school theater include: Jan Poplatek, Studia z dziejów jezuickiego teatru szkolnego w Polsce (Wrocław: Ossolineum, 1957); Jan Okoń, Dramat i teatr szkolny: Sceny jezuickie XVII wieku (Wrocław: Zakład Narodowy im. Ossolińskich, 1970); Okoń, 


\section{The Polish-Lithuanian Province}

The Jesuits began to establish colleges in Europe from the sixteenth century onwards, and it was the outstanding education offered at these schools that led Bishop Stanisław Hozjusz (1504-79) to invite the Jesuits to Poland in 1564 to open their first college, the Collegium Hosianum in Braniewo, or Braunsberg (Fig. 3.1). ${ }^{7}$ The Jesuit college in Wilno (Vilnius), the capital of the Grand Duchy of Lithuania in a long-lasting political union with the Kingdom of Poland, was founded in 1570 with the support of the bishop of Wilno, Walerian Protaszewicz (1514-80). The Wilno college was granted the status of an academy in 1579 by the royal charter of King Stephen Báthory (1533-86, r.1575-86) and the bull of Pope Gregory XIII (1502-85, r.1572-85).

In the period between the foundation of the Wilno Academy and Pope Clement XIV's (1705-74, r.1769-74) dissolution of the order in 1773, the Lithuanian colleges operated within the Austrian province (until 1575) and the

Na scenach jezuickich $w$ dawnej Polsce (rodzimość i europejskość) (Warsaw: Wydawnictwo DiG, 2006); Jerzy Axer, "Polski teatr jezuicki jako teatr polityczny," in Jezuici a kultura polska, ed. Ludwik Grzebień et al. (Cracow: WAM, 1993), 11-21; and Europejskie zwiazki dawnego teatru szkolnego i europejska wspólnota dawnych kalendarzy, ed. Irena Kadulska (Gdańsk: Wydawnictwo Uniwersytetu Gdańskiego, 2003). Publications on Polish Jesuit school theater in other languages include: Jan Okoń, "Recherches sur le théatre jésuite en Pologne au XVI ${ }_{-}$ XVIII ${ }^{\text {e }}$ s." Archivum historicum Societatis Iesu 41 (1972) and "Sul teatro dei gesuiti nell'antica Polonia," AHSI 51 (1982); Okoń, "L'umanesimo gesuitico nella Polonia del Cinque e SeicentoTra Occidente e Oriente," in Acta Conventus Neo-Latini Bariensis: Proceedings of the Ninth International Congress of Neo-Latin Studies, Bari 29 August to 3 September 1994, ed. Rhoda Schnur, Medieval and Renaissance Texts and Studies 184 (Tempe, AZ: Medieval and Renaissance Texts and Studies, 1998), 461-68; and Okoń, "Das Jesuitentheater in Polen und in Europa," in Bohemia jesuitica 1556-2006, ed. Petronella Cemus (Prague: Karlova University, Karolinum Publishers, 2010), 2:971-80.

7 Studies on the history of the Polish-Lithuanian Jesuit province include: Encyklopedia wiedzyo jezuitach na ziemiach Polski i Litwy, 1564-1995 [Encyclopedia of information on the Jesuits in the territories of Poland and Lithuania, 1564-1995], ed. Ludwik Grzebień (Cracow: Wydawnictwo wAM, 2004), http://www.jezuici.krakow.pl/bibl/enc.htm; Kazmierz Puchowski, Jezuickie kolegia szlacheckie w Rzeczypospolitej Obojga Narodów (Gdańsk: Wydawnictwo Uniwersytetu Gdańskiego, 2007); Stanisław Bednarski, Upadek i odrodzenie szkót jezuickich w Polsce (Cracow: Wydawnictwo Księży Jezuitów, 1933/Cracow, Wydawnictwo WAM, 2003); Jezuici a kultura polska, ed. Ludwik Grzebień et al. (Cracow: Wydawnictwo wAM, 1993); Ludwik Piechnik, Dzieje Akademii Wileńskiej [History of Wilno Academy], vol. 1: Początki Akademii Wileńskiej, 1570-1599 (Rome: Jesuit Historical Institute, 1983). On Cardinal Hosius and the earliest Jesuit settlement in Poland, see also Jan Okoń, "Marcin Kromer a jezuici," in Marcin Kromer: Polski Liwiusz z Biecza, ed. Zdzisław Pietrzyk (Gorlice: Starostwo Powiatowe w Gorlicach, Dwory Karwacjanów i Gładyszów w Gorlicach, 2014), 14-41. 


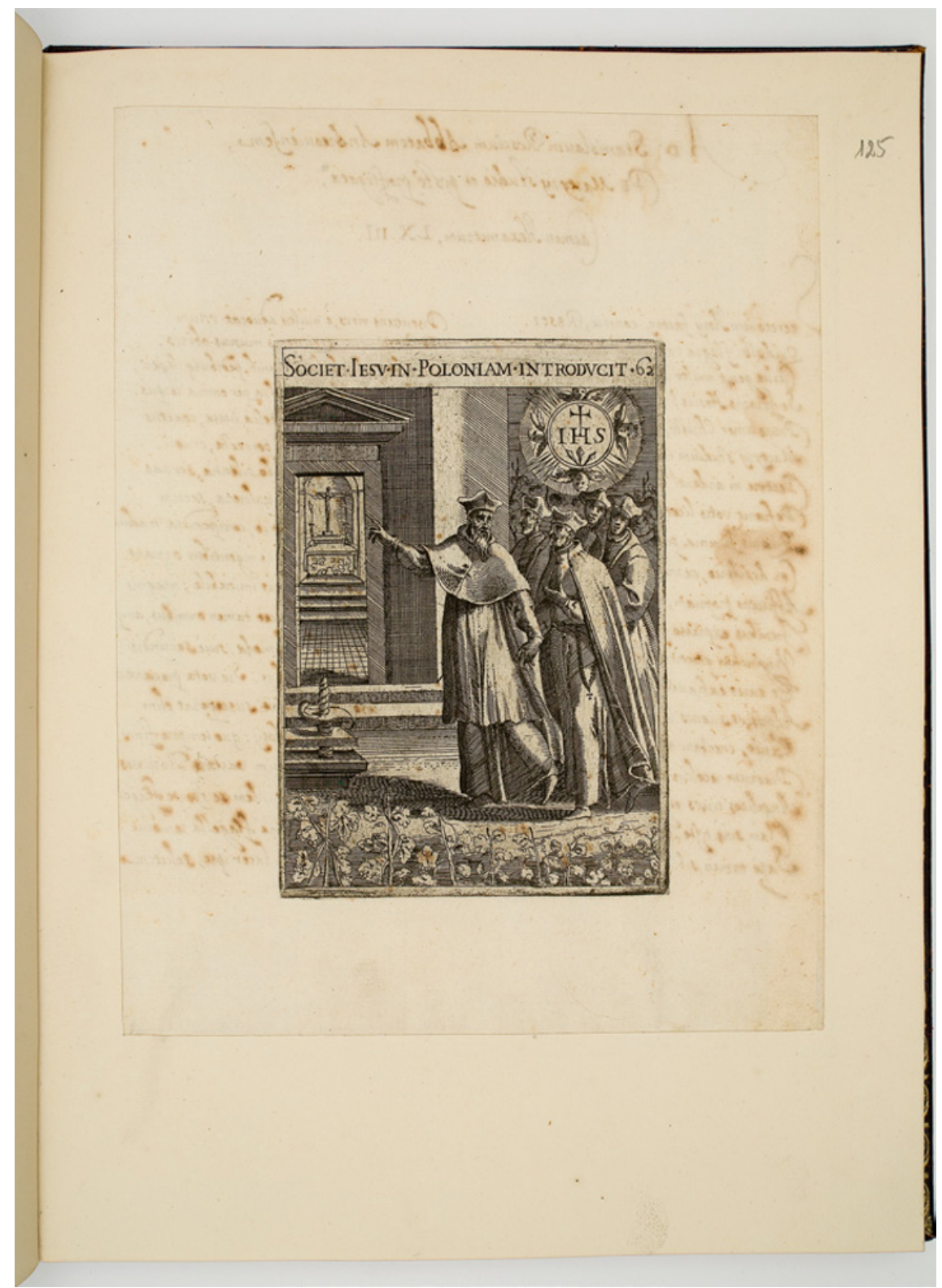

FIGURE 3.1 Cardinal Hosius brings Jesuits to Poland

FROM THOMAS TRETTER, THEATRUM VIRTUTUM D. STANISLAI HOSII

(ROME, 1588). MS CZARTORYSKI LIBRARY 2921, FOL. 125. COURTESY OF THE CZARTORYSKI LIBRARY IN CRACOW 
Polish province (until 1608). The Lithuanian province, established in 1608, was further divided into the Lithuanian and Mazovian provinces in 1759, with colleges in Warsaw, Polotsk, and Vitebsk. Each of these colleges proudly staged elaborate plays and dialogues, as witnessed by the playbills in the libraries of modern Poland and Lithuania-important and little-known documents detailing the Jesuits' educational efforts. ${ }^{8}$

The Polish Jesuits adopted the model of teaching used in the Collegium Romanum. However, at the same time, they took into account the specific Polish need for the civic education of youth, as expressed by Polish parents, school patrons, and donors. ${ }^{9}$ They not only educated their pupils in a modern fashion but also prepared them for their future public roles as members of the political elite by instilling ideas of justice, truth, benevolence, and reverence in the students. The Jesuits arrived in the country during the critical period of the CounterReformation, engaging themselves in religious disputations with the Protestants. In doing so, they were able to benefit from the policies adopted in the multiethnic and multireligious Polish-Lithuanian Commonwealth, which enshrined the principle of religious toleration. ${ }^{10}$ By taking the country's socio-political context into account, the Jesuits were able to establish themselves as tutors, educators, and intellectual leaders of the youth, thus preparing young people for their future public roles as civil servants, state officials, parliamentarians, councilors, and leaders of their communities, people who would be ready to serve their

8 In 1599, there were eleven Jesuit colleges in the Polish-Lithuanian province, and fifty-one in 1700. Bednarski, Upadek i odrodzenie, 21; Ratio studiorum: Ustawa szkolna Towarzystwa Jezusowego, ed. Kalina Bartnicka et al. (Warsaw: Wydawnictwo Naukowe Ateneum, 2000), iii. Dramat staropolski, 2: part 1, xxii-xxiii, lists sixty-nine Jesuit colleges within the political borders of Poland-Lithuania. No playbills have so far been found in sixteen colleges of the list.

$9 \quad$ Kazimierz Puchowski, "Jezuickie kolegium i konwikt szlachecki w Kaliszu: Ze studiów nad edukacją w dawnej Rzeczypospolitej," in Jezuici w przedrozbiorowym Kaliszu, ed. Mariusz Bigiel (Kalisz: Edytor, 1996), 29; see also Puchowski, "In bello Mars, in pace Apollo: Z dziejów edukacji w kolegiach jezuickiej Rzeczypospolitej Obojga Narodów," in Jezuicka ars historica, ed. Marek Inglot et al. (Cracow: Wydawnictwo WAM, 2001); and Puchowski, Edukacja historyczna w jezuickich kolegiach Rzeczypospolitej (Gdańsk: Wydawnictwo Uniwersytetu Gdańskiego, 1999).

10 Poland had a long tradition of legislation encouraging religious and political toleration, starting with the Statute of Kalisz (1264). "Religious toleration was not only official policy in sixteenth-century Poland; it was the law, codified in the 1573 Warsaw Confederation, reputed to be the first document in European history to constitutionalize religious toleration." See Daniel H. Cole, "Poland's 1997 Constitution in Its Historical Context," Faculty Publications, no. 589 (1998), Indiana University, Maurer School of Law, http://www.repository.law.indiana .edu/facpub/589. 
country in times of war and peace. They offered a firm grounding in the arts, introduced elements of national history into the curriculum, and encouraged their pupils to take part in theatrical activities to make them better citizens. The quality and scope of their innovative schooling system were unmatched by any other educational project of the time.

\section{Jesuit School Theater Season}

Jesuit theater was a remarkable artistic phenomenon in the history of early modern Europe and the Polish-Lithuanian Commonwealth. Yet, somewhat paradoxically, elaborate theater plays were not recommended in the Ratio studiorum of 1599. According to these regulations, professors of rhetoric were responsible for composing plays and dialogues, and they were occasionally allowed to stage eclogues, scenes, and dialogues with the students as part of their training in rhetorical skills - this was to be done in the classroom, without any costumes or props, and each student was to have a part." ${ }^{11}$ The general principles of Jesuit education set out first in the Jesuit Constitutions (part 4) and in the Ratio studiorum were to vary with time, place, and circumstance, and were to be adjusted to the particular environment. ${ }^{12}$ Even though the Polish-Lithuanian province had its local schooling customs written down in the custom books, the use of theater in the province's schools went beyond what was contained in these books. They do not provide a satisfactory explanation to the fact that is attested by the plays and playbills, namely that the school theater in the Jesuit schools of the Polish and Lithuanian province was a wellestablished institution and an integral part of the system of education, with plays open to visitors and guests. ${ }^{13}$ The Consuetudines (Custom book) for the Polish and Lithuanian province for 1604-20 expanded the range of theatrical activities in which students could take part, allowing solemn dialogues or comedies with props and decorations, ${ }^{14}$ prologues and intermedia in vernacular

\footnotetext{
11 Bartnicka, Ratio studiorum, 95.

12 Konstytucje Towarzystwa Jezusowego: Część czwarta [Constitutiones Societatis Iesu], trans. Jan Ożóg, in Bartnicka, Ratio studiorum, chapter 13, [454], 25.

13 The number of plays in the Polish-Lithuanian province between 1564 and 1773 has been estimated at thirty thousand, with some performance records still undiscovered, see Bartnicka, Ratio studiorum, v.

14 "Singulis annis haberi potest dialogus semel tantum cum apparatu solemni pro commoditate temporis collegiorum, aliquando loco dialogi comoedia. Consuetudines scholasticae Provinciae Poloniae et Lituanae SJ 1604/1620," in Bednarski, Upadek i odrodzenie, 502. Polish translation by Dr. Katarzyna Gara.
} 
(provided they served as explication of the Latin part of the play), ${ }^{15}$ and vernacular Corpus Christi dialogues staged in churches for the public, with sets and decorations. ${ }^{16}$ They also allowed the Shrovetide dialogues to be staged exclusively for insiders, the Jesuits and their pupils, with the doors closed. ${ }^{17}$ Although provincial regulations concerning school performances were less rigid, this does not explain the outburst of theatrical production in the Jesuit schools of Poland-Lithuania. As the historian Jan Okon states in his groundbreaking study of Jesuit school theater in the Commonwealth, the plays were staged as part of a "theater season" - a yearly cycle involving plays for the inauguration of the school year and prize-giving, plays for college feast days, patron saints' feast days, plays for the visits of important guests, and Shrovetide, Holy Week, and Corpus Christi plays. ${ }^{18}$ The idea of plays being performed at regular intervals in the school year was a novelty, and it therefore has to be underlined as a remarkable and distinctive feature of Jesuit theater. Moreover, the theater season in Jesuit schools became an important educational tool in and of itself.

The regular performance of theater plays is attested by the surviving playtexts and playbills from the colleges of the province that contain information on the occasion, contents, and audience of a given play. With respect to theatrical production and school theater, the Polish (from 1575) and Lithuanian (from 1608) province of the Society went beyond the regulations in the Ratio studiorum both in terms of developing a regular theater season, ${ }^{19}$ and in adjusting the rules to the requirements of the local environment, with philosophy and history being taught much more extensively in Polish-Lithuanian colleges

15 Ibid.: "In huiusmodi dialogis prooemium et intermedia fieri possunt vernaculari lingua, si non sint aliud, quam explication argument subsequntis partis."

16 Ibid.: "In festo Corporis Christi et explicatione doctrinae christianae haberi possunt aliquando breviores et simplices dialogi vernaculari lingua ad populum excitandum in templo, cum aliquot apparatu scenico extemporaneo."

17 Ibid.: "Potest concedere tempore Bacchanaliorum dialogus brevis, etiam scenicum, quasi extemporaneous congregationis nomine, sed privatim intra scholam pro solis scholasticis, ianuis clausis."

18 In his Dramat i teatr szkolny (1970), Jan Okoń has argued that Polish-Lithuanian Jesuit school theater can be viewed in terms of a "theater season." The idea was developed in Okoń, "Barokowy dramat i teatr szkolny w Polsce: Wśród zadań publicznych i religijnych," in Popularny dramat i teatr religijny w Polsce, ed. Irena Sławińska et al. (Lublin: Tow. Nauk. Katolickiego Uniwersytetu Lubelskiego, 1990), 7-26. He argues that the "theater season" concept is applicable to the Jesuit school theaters all over Europe.

19 Bartnicka, Ratio Studiorum, v. 
than was the case elsewhere; ${ }^{20}$ the Jesuits also favored the Baroque rather than the prescribed Ciceronian style in the teaching of rhetoric in the PolishLithuanian colleges. ${ }^{21}$ As Kazimierz Puchowski, a historian of Jesuit schools in Poland, suggests, the inclusion of history teaching and national themes in Polish-Lithuanian school theater stemmed from the social background of the second and third generation of the Polish-Lithuanian Jesuits, together with pressure from the students' parents, as the schools were expected to educate members of the political elite, defenders of fides et patria (faith and country). ${ }^{22}$

Hence while extensive theater practice was part of the curricula of all Jesuit educational institutions, this was especially the case in the colleges of the Polish-Lithuanian province. Dramatic performances and full-fledged plays were a means of practicing rhetorical skills, public speaking, and, last but not least, a way to promote the school's achievements in a given town and region. They were also intended to shape their pupils' personalities, with the aim of molding them into responsible members of their communities who could serve their republican country — "the Republic of Nobles" — presided over by an elected king.

An examination of plays and playbills from the perspective of the calendar for the school year shows that the beginning of the year (renovatio autumni) was accompanied by plays on the virtue of individual prudence, as each student was called to work on his character, develop personal piety, and broaden his knowledge. ${ }^{23}$ In addition, beginning-of-the-year plays were usually an

20 Roman Darowski, "Filozofia jezuitów w Polsce od XVI do XVıII wieku: Próba syntezy," in Grzebień et al., Jezuici a kultura polska, 51-74; Darowski, "Przepisy dotyczące nauczania filozofii w uczelniach jezuickich w Polsce w XVI wieku," in Studia z historii filozofii: Księga pamiątkowa z okazji 5o-lecia pracy naukowej ks. Pawta Siwka S.J., ed. Roman Darowski (Cracow: WAM, 1990). Teaching of history went on in the Polish and Lithuanian Jesuit province before 1599; for example, in Poznań it was taught by Jan Laus (1557-91) from Flanders between 1585 and 1590, and in Lublin. Ludwik Piechnik, "Działalność jezuitów na polu szkolnictwa (1565-1773)," in Grzebień et al., Jezuici a kultura polska, 246.

21 Rather than the Ciceronian style recommended in the Ratio studiorum, seventeenthcentury Polish-Lithuanian colleges practiced the florid "Baroque" style of rhetoric, represented, for example, by Jan Kwiatkiewicz, S.J. (1629-1703), author of treatises on Baroque rhetoric: Phoenix rhetorum (1627) and Eloquentia reconditor (1698). Bartnicka, Ratio studiorum, v. For more on Kwiatkiewicz, see Puchowski, "Jezuickie kolegium i konwikt szlachecki w Kaliszu," 31-32, and Zofia Rynduch, "Jana Kwiatkiewicza Phoenix rhetorum jako traktat o wymowie barokowej," Zeszyty naukowe Wydziatu Historycznego wso w Gdańsku 1 (1962).

22 Puchowski, “Jezuickie kolegium," 3 .

23 The school year began on September 1; holidays lasted one month (August); and holiday breaks were very short (four days at Christmas and Easter). July was set for revision and 
accompaniment to the prize-giving (pro distribuendis praemiis), as in most colleges the exam results which had been privately announced to the students in July would then be announced in public in September. ${ }^{24}$ Mercury, Apollo, and the Muses made frequent appearances on the school stage at that time of year to give prizes and to pass on congratulations and words of instruction to students for the coming school year. ${ }^{25}$

Shrovetide plays (Bacchanalia) focused on the virtue of temperance and moderation. The approaching period of Lent also called for themes of abstinence and moderation to be presented on stage. ${ }^{26}$ While in the days before Lent it was the class of poetry students who performed allegorical plays about the duties and obligations of a member of a community, ${ }^{27}$ the Holy Week dialogues and passion plays were most often the domain of the class of rhetoric. ${ }^{28}$ The end of the school year had the richest conceptual framework: communal wisdom and prudence were at the center of the plays. Appropriate role modelsof prudent kings and leaders-were selected for the stage, as the general

examinations. Exam results were announced to students privately in the last days of July and the college closed on the Feast of St. Ignatius of Loyola (July 31). On September 1, examination results were officially announced, followed by solemn speeches, dialogues, and prize distribution. Bednarski, Upadek $i$ odrodzenie, 109. It was for the inauguration of the 1592 school year that Ambrosiana, a play by Edmund Campion (1540-81), professor of rhetoric in Prague, was performed in Kalisz. The context of the performance is discussed in my chapter "English Recusants in the Jesuit Theatre of the Polish-Lithuanian Commonwealth," to be published in a volume as part of Brill's Library of the Written Word series (Brill, forthcoming).

24 Bednarski, Upadek i odrodzenie, 109.

25 Occasionally, prize-giving was organized at the end of the school year, as for example with a 1690 play from Wilno, Pietas literata de ambitione, fraude, rebellione triumphans in Arcadio; playbill discussed in Dramat staropolski, 2: part 1, no. 531. The play celebrates the power of wisdom and its triumph over brute force. See Okoń, Dramat i teatr szkolny, 34, 45, 217-18, 231, 252, 329-30.

26 In Poland-Lithuania, Jesuits were the promoters of the Forty Hours' Devotion in the Lenten period, and therefore Shrovetide plays would often conclude with a call to begin the devotion.

27 In Poland, the class of humanitas was called a class of poetry and prepared students for the study of rhetoric. The instruction focused on reading historical works: Cicero's $D e$ officiis, Virgil's Aeneid, Horace's Odes, Caesar's De bello gallico, epigrams by Martial (38/41$102 / 4 \mathrm{CE}$ ), and selected works by Hesiod (fl. c.700 BCE) and Gregory of Nazianzus (c.330c.389). Bednarski, Upadek i odrodzenie, 107.

28 The class of rhetoric focused on the theory and practice of rhetoric in order to achieve perfecta eloquentia. The students studied Cicero's works on rhetorical theory: De oratore and Partitiones oratoriae, a treatise on rhetoric Ad Herennium, Cicero's speeches, works by Seneca, Livy, Tacitus, Iliad, and epigrams and speeches by Demosthenes. Ibid. 
understanding was that after a yearly period of study the students would go back home and become wise and pious members of their communities.

The idea of a school theater season is most evident in the college playbooks where plays by college authors were written down, rather than those imported from other colleges. However, where possible, playbook information has to be supplemented with information from the playbills and from the Litterae annuae (yearly reports on the progress of the college), since plays that were "borrowed" from other colleges would only be mentioned in the regular reports sent from each country to the main provincial archive in Rome. ${ }^{29} \mathrm{~A}$ very early example of a Jesuit school theater season can be found in a playbook from the college of Kalisz in Greater Poland (Collegium Karnkovianum) in the so-called Pawlikowski Codex (1584-1703). ${ }^{30}$ It is one of three surviving playbooks from the second half of the sixteenth century, and therefore of exceptional value to historians of theater. ${ }^{31}$

The Pawlikowski playbook gives a glimpse of what a typical school theater season was like as it copies playtexts or play titles produced in the college in the order of the school year (with minor deviations from the established order). Interestingly, some of the play titles contain a note, "you will find this play in the book of comedies," which suggests there was another book of plays in the college. ${ }^{32}$ The Pawlikowski Codex lists plays for the inauguration of the

29 The Polish province sent its Litterae annuae to Rome from 1581: Polonica $w$ Archiwum Rzymskim Towarzystwa Jezusowego, vol. 1: Polonia, ed. Andrzej Paweł Bieś et al. (Cracow: Wydawnictwo WAM, 2002), 1. This is the case with Campion's play Ambrosiana, performed in Kalisz in 1592 and mentioned in the Litterae annuae, of which there is no sign in the surviving college playbook, MS Ossol., Bibl. Pawlikowskich no. 204 from roughly the same period.

30 MS Ossolineum Library, Bibl. Pawlikowskich no. 204. The codex lists full-text plays, speeches, and intermedia of the Kalisz Jesuit school theater from 1584 to 1703 . The contents of the manuscript can be found in Ludwik Bernacki, "Dwa najstarsze jezuickie intermedia szkolne," Pamiętnik literacki 2 (1903): 101-14, and Bibliografia literatury polskiej: Nowy Korbut, vol. 1: Piśmiennictwo staropolskie, part 1, Hasta ogólne i anonimowe, ed. Roman Pollak, no. 11 (Warsaw: IBL, 1963), 206-7.

31 The only other two late sixteenth-century playbooks from Poland-Lithuania are: MS Ossolineum Library 1137 (the so-called Pętkowski Codex), which contains plays and dialogues in Greek and Latin written by Kasper Pętkowski (Gaspar Pentkovius) (1554-1612) from the Wilno Academy, and Ms Uppsala Library R 380 (the so-called Codex Upsaliensis), containing plays from the Poznań Jesuit college.

32 Ms Ossol., Bibl. Pawlikowskich no. 204, fol. 107r: "Hos in libro comediarum invenies." Under the year 1588 , on fol. $106 \mathrm{v}$ of the same Ms, there is a note next to the title of Philoplutus comoedia: "quae est in libro comediarum." Thus, it can be concluded that Kalisz had at least two playbooks at the time, one of which is perhaps yet to be discovered. 
school year and prize-giving (renovatio autumni); ${ }^{33}$ numerous plays and dialogues for the Feast of St. Catherine of Alexandria (287-305), the patron saint of Jesuit students; ${ }^{34}$ Christmas tide plays (including Christmas Day and the Feast of the Holy Innocents on December 28$) ; 35$ plays for the beginning of the spring term (verna renovatio); ${ }^{36}$ plays for Shrovetide; ${ }^{37}$ plays for the Holy Week; plays for the beginning of the summer term (renovatio aestiva); ${ }^{38}$ vernacular plays for the Feast of the Corpus Christi (including plays for the Corpus Christi octave); ${ }^{39}$ and plays for the Feast of St. Ignatius of Loyola, which concluded the school year (July 31). ${ }^{40}$ Each of these plays highlights a moral stance, a virtue,

33 Dialogus, in renovatione prima studiorum, Calissii, anno Domini 1584 tempore autumni facta, exhibitus, Ms Pawl. 204, fol. 1-22; In renovatione autumni tempore facta anno (15)85. Mercurius pro distribuendis praemiis etc. (praesesserunt carmina), fol. 29-30. In autumno [1588] Philoplutus comoedia [...] quae est in libro comoediarum, fol. 106-7 (notes). In autumno [1590] Tragicomoedia Philocarchangelus. Hos in libro comaediarum invenies, fol. 106-7 (notes), Anno Domini tragoedia Juditae in autumn fuit exhibita, fol. 106-7 (notes).

34 Dialogus in festo S. Catharinae exhibitus anno Domini 1584, fol. 30-36; Dialogus de vera Christianorum philosophia in festo sanctae Catharinae exhibitus anno Domini 1586, fol. 37-56.

35 Dialogus in Natali Domini habitus anno Domini 1586, fol. 56-65.

$36 \quad$ Mopsi adolescentis de vitae genere in dialogum redacta deliberatio (in verna renovatione studiorum a.D. 1585), including Carmen ante dialogum recitatum, gratiarum actione post dialogum, fol. 29-30. Verna renovatione A.D. 159 o comoedia Diogenes, fol. 106-7 (a note).

37 Dialogus Ergastus seu modesti adolescentis in Bach. Idea, fol. 108-14. Dolus doloris comes seu improvisa Mahometis supreme Tartarorum ducis eadem, quam fratri intentaveramt poena, celsio [...] infra ferias Bacchanaliorum exhibita, fol. 213-21, includes intermedium cantus: De licentia juventutis, a choir and epilogue in Polish.

38 Renovatione aestiva exhibitus est dialogus tempori serviens, anno Domini1588, fol. 106-7 (notes).

39 Anno 1608 Dominico die infra octavam Corporis Christi datus est in templo dialogus polonus de puero a patre Iudaeo in fornacem ardentem ob sumptum Venerabile Sacramentum coniecto, fol. 115 (a note). Anno 1609 Dominico die infra octavam Corporis Christi exhibitus est sequens dialogus in templo nostro horis praemeridianis. Viator: Dialogus de ligno vitae [in Polish], fol. 117-26. Some of the early seventeenth-century plays, including Viator:Dialogus de ligno vitae (Kalisz, 1609) have been edited by Jan Okoń in Dramaty eucharystyczne jezuitów: XVII wiek (Warsaw: Instytut Wydawniczy Pax, 1992). On the tradition of Corpus Christi plays in Poland, see Okoń, Dramat iteatr szkolny, 80-107, Encyklopedia katolicka, vol. 2 (Lublin: Towarzystwo Naukowe Katolickiego Uniwersytetu Lubelskiego, 1975), Okoń, "Les processions baroques de la fête: Dieu comme exemple de spectacles des rues," in La commedia dell'arte, le théâtre forain et les spectacles de plein air en Europe XVI ${ }^{e}-X V I I I^{e}$ siècles, ed. Irène Mamczarz et al. (Paris: Klincksieck, 1998), 217-30, and Andrzej Dąbrówka, "Anything but a Game: Corpus Christi in Poland," Quaestiones Medii Aevi novae 7 (2002): 245-70.

Terminus anni literarii principiis S. Ignatii coronatus seu Heroica ab Ignatio saeculi conculcatio in scenam data ad decursum anni literarii 1699 a rhetoribus Karnkoviani Collegii, fol. $135^{-41 .}$ 
or an attitude the Jesuits thought necessary to pass on to their students. For example, a prize-giving play from Kalisz features Mercury, god of eloquence and thus of poetry, as well as an ancient patron of communication. He is the one who brings good news to the students regarding their promotion to the next class and asks them to be persistent in their studies. The group of plays and dialogues dedicated to St. Catherine of Alexandria celebrates her as the person who denounced the worship of false gods and effected numerous conversions. The Jesuits chose her as the patron saint in their apostolic work in the challenging environment of multireligious Poland-Lithuania, and Litterae annuae regularly note the number of converts who went through the college of Kalisz. The Pawlikowski Codex clearly breaks into two parts, the second one beginning around 1608 , when extremely long and elaborate plays start to appear (including night performances, full plays in Polish, and historical plays on Polish saints and rulers) ${ }^{41}$ However, this is exactly the point where information on Kalisz school theater is superseded by that contained in the playbills, which, despite their limitations in other respects, expand the context in which Jesuit school drama can be analyzed.

\section{The Playbills-A Forgotten Treasure}

School theater playbills constitute part of the fascinating and largely forgotten heritage of early modern Poland-Lithuania. As dramatic records, they are important documents of early modern cultural life. The playbills' content and structure suggest they were employed in early modern literary culture to influence student actors and audiences-either by confirming their beliefs and viewpoints or by trying to change their moral, religious, or political convictions and conduct. The wealth of information contained on four pages of a typical Jesuit playbill allows for a close analysis of the topics selected for the stage in a given college at a particular time, and how and to what extent the use of classical sources for drama was balanced by topics and themes in national history. ${ }^{42}$

41 St. Stanisław Kostka plays on fol. 130-32 (1698), fol. 178 (c.1704). Drama de S. Casimiro, fol. 182-87 (1705).

42 Polish studies of theater playbills include: Wanda Roszkowska, "Uwagi o programowości teatru barokowego w Polsce," 47-79; Władysław Korotaj, "Z problematyki staropolskich programów teatralnych," 81-109; and Tadeusz Bieńkowski, "Na marginesie lektury staropolskich programów teatralnych," in Wroctawskie spotkania teatralne, ed. Wanda Roszkowska (Wrocław: Zakład Narodowy im. Ossolińskich, 1967), 111-19. The "grammar" of playbills has been discussed by Okoń in Dramat i teatr szkolny, 12-79. 
Playbills also inform us about the context of the performance, its patrons, theater groups, and the names of the actors involved.

The earliest playbill from the Polish-Lithuanian province is a 1614 print summarizing a Corpus Christi procession in Wilno. ${ }^{43}$ The existence of several playbills produced in the years that followed testifies to their use in the other main colleges of Poland and Lithuania. ${ }^{44}$ There are a number of playbills from Kalisz that do not have a corresponding playtext from the Pawlikowski Codex. In fact, playbills from Kalisz are one of the earliest surviving playbills from PolandLithuania. In 1623, the Polish king Sigismund III Vasa (1566-1632, r.1587-1632) visited the college of Kalisz and a play was staged on that occasion entitled Sigismundus I rex Poloniae - a play about his predecessor, King Sigismund of the Jagiellonian dynasty $\left(1467-1548\right.$, r.1506-1548). ${ }^{45}$ The staging of the play was clearly an attempt to build an elaborate analogy between the great king of what was later called Poland's Golden Age and the present ruling monarch who, through his mother, the Jagiellonian princess Catherine $(1526-83$, queen of Sweden 1569-83), was heir to the Jagiellonian throne. The playbill summarizes the play: an allegorical representation of the victory of King Sigismund I at the Battle of Orsha against the Muscovites in 1514. The leader of the Muscovite army Ivan Chelyadnin (d.1514in Wilno), is punished for hisvanity by thePolish king and taken into captivity. In the final scene, the student actors tell King Sigismund III Vasa that his predecessor's personality and the deeds depicted in the play symbolize the present king and his deeds. ${ }^{46}$ The Polish playbill of the same play ${ }^{47}$ summarizes elaborate scenes of legendary Polish rulers as well as early Polish princes and kings sending their support from the heavens. ${ }^{48}$ Both the Latin and Polish synopses of the play show that it was based on an extensive selection of works on the history of Poland-Lithuania and the Grand Duchy of Moscow. ${ }^{49}$ This would

43 Okoń, Dramat i teatr szkolny, 16. It is not listed in Dramat staropolski 2: part 1. The earliest playbill from Wilno in the catalog is Summarium tragoediae Eustachianae (1616), listed as no. 509, 419-20.

44 Okoń, Dramat i teatr szkolny, 16.

45 Dramat staropolski 2: part 1, no. 140 and no. 141., 94-56. There were two playbills printed on the occasion, a Latin and a Polish one; the Polish is more elaborate and detailed.

46 Ibid., 94.

47 Na szczęśliwy przyjazd Nayiaśnieyszego Zygmunta III, króla polskiego i szwedzkiego, Zygmunt I, król Polski, w kaliskiem kollegium Societatis wystawiony (Kalisz: A. Gedeliusz, 1623). Dramat staropolski, 2: part 1, no. 141, 95-96.

48 Lech sends Verve (Animusz), Boleslaus the Brave sends Stateliness (Stateczność), Boleslaus the Wrymouth sends Courage, Dramat staropolski, 2: part 1, 96.

49 Iodocus Ludovicus Decius, De Sigismundi I temporibus, Stanisław Sarnicki (Stanislaus Sarnicius), Annales sive de origine et rebus gestis Polonorum et Lituanorum. Lib. 7, Maciej 
not have been possible had the professors and students of the college not studied the national history and familiarized themselves with the works of the major historians of Poland-Lithuania: in this case, mainly with the works of Maciej Stryjkowski (c.1547-before 1593). It can be concluded that the Sigismundus I play from Kalisz, with its clear allegorical line and well-spelled out historical analogy, illustrates an early trend in Polish-Lithuanian school theater for combining classical education with themes in national history.

As a later playbook from the same college shows, the focus on national themes in Kalisz continued well into the eighteenth century. ${ }^{50}$ In the plays from this collection, an allegorical figure of Polonia (Poland), dressed as an ancient goddess, Pallas, makes frequent appearances, as well as the legendary Polish rulers, including the country's first legendary ruler, Lech..$^{51}$ A play from the 1712/13 school year features the Polish eagle of freedom and members of the Polish nobility being urged by Fortuna not to fall into Morpheus's trap when Mars is approaching. ${ }^{52}$ Ancient Polish rulers appear in yet another dialogue from 1712/13, whose playbill can be found in the same manuscript. The main theme of the play is the traps set by ambition and immaturity, and the students are encouraged in a Polish intermedium to be prudent and thoughtful. ${ }^{53}$ Next comes a play fragment on the victorious Battle of Khotyn (Chocim) in $1621,{ }^{54}$ which testifies to the interest of the college's Jesuit professors in Polish history.

Historians of Jesuit school theater tend to agree that the Jesuit stage was completely immersed in historical topics.55 Indeed, upon looking at the playbills

Stryjkowski, Kronika polska, litewska, Alexander Guagninus, Compendium chronicorum Poloniae, Paulus Jovius, Elogia virorum bellica virtute illustrium, Sigismund von Herberstein, Rerum Moscoviticarum commentarii, Dramat staropolski, 2: part 1, 94, 96.

50 Ms Jagiellonian Library 182, the so-called Jagiellonian Codex IV from 1711-26. The contents and the authors of plays are discussed by Okoń in "Autorzy tekstów dramatycznych w rękopisie 182 Biblioteki Jagiellońskiej," Biuletyn Biblioteki Jagiellońskiej 21 (1971): 105-33. Polonia Pallas in a 1712/13 play, Sol in agno serenum scientiis, Ms Jagiellonian Library 182, fol. $28 \mathrm{r}$, playbill in MS in fol. $28 \mathrm{r}-28 \mathrm{v}$. Polonia appears in St. Stanisław Kostka's play (1712/13), B. Stanislaus Kostka Ganimedes Lechicus, fol. 51v.

52 Somnus Timothei retia inducit in Poloniam libertatem aquilae unguibus facile disrumpenda (1712/13), fol. $97 \mathrm{v}-98 \mathrm{v}$.

53 Menstrua major senium ambitionis in immaturo Ratislao Lesci filio (1712/13), fol. 66v-67, playbill in MS in fol. $67 \mathrm{v}-74 \mathrm{v}$.

54 Triumphus Poloniae ad Chocimum, fol. 95v.

55 Małgorzata Puchowska, "Wątki historyczne na scenie jezuickiej w Kaliszu," in Bigiel, Jezuici w przedrozbiorowym Kaliszu, 78-85, Kazimierz Puchowski, "Recepcja dzieł Marcina Kromera w polskich kolegiach jezuickich do 1773 roku," Studia warmińskie 26 (1989): 113-20, Puchowski, "In bello Mars, in pace Apollo," 479-97. 
from just one source, such as the Academy of Wilno, one is immediately struck by the variety and invention in the use of themes from national history and historical allegories. After the 1683 battle of Vienna, for instance, the Jesuits launched a series of plays to celebrate the victory, some of which were based on King John III Sobieski's (1629-96, r.1674-96) letter to his wife, written on the night after the battle. ${ }^{56}$ The bibliographical collection of Jesuit playbills from the Wilno Academy lists numerous plays on the legendary pagan rulers of Lithuania as well as military leaders and local saints.

\section{Republican Ideas and Civic Virtues on Stage}

The Jesuit educational system in seventeenth- and eighteenth-century PolandLithuania fostered civic virtues in their students. Most of the playbills reveal the literary and historical sources used in making the play. In the dramatis personae part, they frequently enumerate the allegorical figures who appear on stage. These figures personify the cardinal virtues, passions, and qualities of a person who was to become a responsible member of a "Noble's Republic." Although many school plays were panegyric — especially those staged to mark visits by distinguished guests - the general underlying assumption was that the presence of guests was a good occasion to promote virtuous conduct and set an example to the students who came from the same political class. One of the main tasks of the colleges was

to train a future public speaker for the country, to educate a politician and a debater who would support the kingdom with his counsel at local parliamentary sessions, in Sejm [the Diet], during various public and special meetings and deliberations, home and abroad, at war and peace. ${ }^{57}$

The culture of disputation in Poland-Lithuania was a direct consequence of a political system based on the concept of freedom and political consent within

56 [Puciłowski, Krzysztof], Victoria Mariae seu Vienna Austriae [...] (1686), Dramat staropolski, 2: part 1, no. 522, a discussion of Vienna battle plays in the Polish-Lithuanian Jesuit theater by Okoń in Giovanni Sobieski e il terzo centenario della riscossa di Vienna: Una crociata o una svolta politica, ed. Richard C. Lewańki (Udine: Istituto di Lingue e Letterature dell'Europa Orientale dell'Università di Udine, 1986), 251-67, Kazimierz Puchowski, "Wiktoria wiedeńska (1683) w teatrze jezuickim," Horyzonty wiary 13 (1992): 67-80. Jan Bielski, Widok Królestwa Polskiego (Poznań, 1763), quoted in Puchowski, "Jezuickie kolegium i konwikt szlachecki," 41. Translation mine. See also Puchowski, "In bello Mars, in pace Apollo," 479. 
the equestrian estate. Parliamentary sessions, as well as sessions of local assemblies (sejmiki), consisted of a series of speeches. The themes of civic virtues and the model citizen were frequently chosen for speeches and disputes by the students in the class of rhetoric in Jesuit colleges; the same themes were presented on the school theater stage too. The Jesuits presented their students with classical models of perfect rulers, kings, and statesmen. At the same time, they would look for role models among mythological, biblical, and classical (Greek and especially Roman) heroes, as well as heroes and rulers of ancient Poland and Lithuania. For panegyric reasons, when offering praise to a distinguished guest, they would draw an analogy between the guest's accomplishments and a historical character (anti-heroes would be presented in much the same allegorical vein). Thus, in Polish school plays, King Władysław IV Waza $\left(1595^{-1648, ~ r .1632-48)}\right.$ was presented as the new Alexander or Mars (the names used for the characters in the plays when performed were Alexander Sarmaticus, or Mars Polonus); the fourteenth-century reformer King Kazimierz the Great (1310-70, r.1333-70), who was called the Sarmatian Lycurgus; and Kęstutis (c.1297-1382), the pagan grand duke of Lithuania (r.1342-82) who was regarded as a chivalrous warrior, protector of the nation, and guardian of the ancient faith, was called Odysseus and Achilles, representing wisdom and courage. ${ }^{58}$ The Jesuit students learned about these historical figures in extensive detail, which in turn helped them become virtuous and responsible citizens while learning about their national history and taking pride in the historical achievements of Poland-Lithuania. ${ }^{59}$

\section{Grandia monumenta, Lublin 1723}

An interesting example of a Jesuit play produced in a civic context is Grandia monumenta religionis Clodoaldi Daniae regis, which was staged on August 8, 10, and 11,1726 , in the town of Lublin in eastern Poland. ${ }^{60}$

$5^{8}$ Puchowski, "Jezuickie kolegium," 32, 38-40.

59 Dramatic argument was often based on an allegorical interpretation.

6o Title page: "GRANDIA MONUMENTA RELIGIONIS CLODOALDI DANIAE REGIS ET FORTITUDINIS CAROLI MAGNI Per Haeresis \& temporis injuriam COLLAPSE ZELO ORTHODOXO ILLUSTRUSSIMORUM \& REVERENDISSIMORUM TRIBUNALIS REGNI, COLLEGII SPIRITUALIS JUDICUM Et Fortitudine. ILLUSTRISSIMORUM EXCELLETISSIMORUM AMAENIORIS PURPURAE PROCERUM, RESTAURATA. In Publico Theatro Collegii Anno Domini 1726. Mense Augusto Die 8, 10, 11. Typis Collegii Societatis JESU. BJ 33629-III. Prof. Okon kindly brought to my attention the playbill of Grandia monumenta (Lublin, 1726) and the fascinating interplay of political, cultural, and didactic themes in 
A careful study of the playbill's title and dedicatory pages reveals that the students of the Jesuit college had an extended school year in 1726 so they could participate in a play for the members of the Crown Tribunal-the highest appeal court in the Polish kingdom and one of its most remarkable republican institutions.

The status of the Lublin performance becomes clear once the role of the Crown Tribunal is considered in the political life of the Polish-Lithuanian Commonwealth. The Crown Tribunal was established in 1578 following a parliamentary resolution to exclude members of the noble estate from royal jurisdiction. ${ }^{61}$ The tribunal held judicial power in the Republic of Nobles and was separated from the executive power of the king and the legislative power of the parliament. The court's deputies (secular and spiritual) were elected at local parliaments for one year. According to Oswald Balzer (1858-1933), a historian of the Crown Tribunal, its sessions "incited such a vast interest among the nobility that it sometimes exceeded that shown in the sessions of the parliament." ${ }^{\prime 2}$ The tribunal had been based in the town of Lublin since the early days of the institution. Interestingly, the Crown Tribunal's judges were not expected to have any formal legal training; however, they did have to be prudent, honest, and trustworthy. Much emphasis was placed on their familiarity with the laws, traditions, and customs of the land. All decisions of the Crown Tribunal were made by consensus.

The composition of the Crown Tribunal and its modus operandi were largely based on the virtuous conduct of its members, on their knowledge of the past, and on their virtuous conduct. The deputies were to live a virtuous life, to practice virtue, and to serve the common good of the multi-denominational country. It was to the citizens who shared these political and civic values that the Jesuit students addressed their play based on the story of King Clodoaldus, the Dane.

The front matter of the playbill consists of an elaborate title page and dedication listing the names and titles of thirty-four spiritual and secular Crown Tribunal judges, with special honors paid to Rev. Hieronim Wysocki and Stanisław Potocki, president and marshal of the Crown Tribunal respectively. ${ }^{63}$

this performance for the members of the Crown Tribunal. The playbill was discussed in a separate chapter in Okoń, Dramat i teatr, 140-55. The playbill is listed in Dramat staropolski, 2: part 1, no. 183, 137-38.

61 Oswald Balzer, Geneza trybunatu koronnego, trans. Piotr Woźniak (Warsaw: Muzeum Historii Polski, 2009), 354.

62 Ibid.

63 BJ 33629-III, fol. A2r-B2v. 
The list of the judges' names is followed by a dedication starting with an invocation, "Celsissimi Iudices," signed by "Oratores Collegii Lublinensis Societatis Jesu." 64 It is only after the elaborate dedicatory part that the synopsis of the play is presented to the reader.

The play is a dramatic rendition of the story of a Danish king, Clodoaldus, based on the chronicle of Albert Krantz (c.1450-1517), Chronica regnorum aquilonarium Daniae, Sveciae, et Norvegiae (Strasbourg, 1546), and on the work of a French Jesuit, Nicolas Caussin (1583-1651). ${ }^{65}$ In the play, Clodoaldus, king of the Danes, loses a battle with Charlemagne and signs a peace treaty. The play features legendary characters and fictitious events including a court conspiracy, an attack by pirates at sea, an army rebellion, and a scene reminiscent of the biblical story of Jephthah, whereby a Clodoaldus, the father, is about to fulfill a rash vow to the pagan god Irminsul by sacrificing one of his sons. Clodoaldus undergoes a religious conversion, and his sight is restored as a result of his spiritual enlightenment. Despite the twists of the plot, the play's main theme stands clear: the fall of heresy and injustice and the restoration of faith, justice, and communal wisdom.

What makes the performance stand out in the series of Jesuit allegorical plays is its political and civic performance context. Since the playbill contains a dedication to the members of the Crown Tribunal, it is worth looking at the ways Jesuit educators addressed the deputies of the highest court of the Polish nobility. The entire speech is based on the principle of paradox and employs legal as well as theological jargon. ${ }^{66}$ In the opening lines, Lublin rhetoricians admit that the "theatrical Pallas" is guilty of a crime. Pallas, the ancient goddess of wisdom, courage, law, and justice, as well as the arts, is evoked to link law and legal proceedings with the art of the theater. "What is her offense?"- ask the Jesuit rhetoricians. They answer that nearly two generations have passed, and neither Comus (the comic actor) nor Tragedus (the tragic actor) has made their appearance on the stage to praise the Polish Areopagus. The rhetoricians consider this fact an offense and a sin of neglect, since they believe "Sarmatian Justinians" deserve the highest praise in theater as the principal guardians of the country's common good. The argument is carried on in the form of the legal speech of the defense and concludes by stating that it is right and just to use theatrical means to help recover those who tend to the country's good. "Theatrical Pallas" is portrayed in the speech as a shrewd, if somewhat procrastinating, companion of

\footnotetext{
64 The dedicatory speech is on fol. B2r-B2v.

65 Albert Krantz, Chronica regnorum aquilonarium Daniae, Sveciae, et Norvegiae (Strasbourg, 1546), Nicolas Coussin, S.J., De symbolica Aegyptiorum sapientia.

66 Translation from Latin by Dr. Katarzyna Gara.
} 
the deputies. The Crown Tribunal deputies who are present at the performance are invited to ponder the effects of idolatry represented in the story of Clodoaldus and the blessings of the true faith (represented in the play by Charlemagne).

Just as the dedication written by the Jesuits extolled the ancient Sarmatian legal tradition upon which the Polish Commonwealth and its principal legal institutions was built, so the play itself revolved around the model of the Christian prince, virtuous statesmen, and the defeat of heresy. The play, its synopsis, and the Crown Tribunal itself belong to the same cultural space in which civic values and virtues were defined, discussed, and promoted. The playbill attests to the way in which theater interacted in form and content with civic institutions. The 1726 Lublin performance of Grandia monumenta and the Crown Tribunal session held in the town at the same time can be considered as participating in the same world, interacting, referring to, and complementing each other. They stand as parallel expressions of the same ideas and, what is more, they engage in a dialogue in which their creators drew from viewers' experience and knowledge about the common good from other fields.

\section{Conclusion}

Despite their strong didactic and panegyric twist, the playbills document the fact that the Jesuit school theater of the Polish-Lithuanian province had a distinctive role in shaping the models of virtuous citizenry in Poland-Lithuania in the seventeenth and eighteenth centuries. The cardinal virtues of prudence, courage, justice, and temperance were to be learned and practiced through drama to secure the divine gift of freedom for the nobility. In other words, the play helped the nobility develop national pride and strengthened their sense of responsibility and solidarity.

It was through drama that the civic virtues were taught to students of Jesuit colleges in the Polish-Lithuanian Commonwealth. The interest of the PolishLithuanian Jesuits in teaching history and in the production of school plays based on historical sources suggests they attempted to tune their model of education to the needs of a country which cherished classical republican ideas and whose political thinkers constantly discussed the nature and goals of political community, the arrangement of its political institutions, and the roles and duties of its citizens and rulers.

The introductory part of a typical playbill from the Polish and Lithuanian province includes an anti-prologue (antiprologus, archiprologus, protoprolo$g u s$ ), which came before the prologue proper and presented a symbolic interpretation of the main character and the argument of the play. Interestingly, the 
antiprologus was often based on a symbolic interpretation of the coat of arms of the main addressee of the play and the person praised. As the historian Kazimierz Puchowski notes in his research on the seventeenth-century Polish Jesuit treatises on rhetoric, the professors of rhetoric, Jan Kwiatkiewicz (16291703), Bogumił Teofil Rutka (1622-1700), and Albert Ines (1619-58), put great emphasis on the use of the coat of arms in the study and practice of rhetoric, since their origins could be traced back to moments of bravery and military accomplishments in the service of the country. Thus, each coat of arms was a token of virtuous conduct of the first generation of a noble family and therefore deserved to be celebrated to promote virtuous conduct among the young members of the nobility. ${ }^{67}$ The history and symbolic imagery of the noblemen's coats of arms were used in the dramatic argument, and they provided the narrative structure to school dialogues and short allegorical scenes. In fact, their widespread use in the Jesuit school theater of Poland-Lithuania marks the moment when the Jesuit educational aim, docta et eloquens pietas, met the expectations of the students and their parents who belonged to the politically dominant equestrian estate and cherished the idea of an elective monarchy.

The predilection for heraldic symbols, the insistence on the teaching of the cardinal virtues, and setting role models more than met the educational ideal established by early Jesuits. In Poland-Lithuania, a political nation which cherished liberty, government by consent, and self-reliance, instruction in the virtues had political as well as religious roots and consequences. As the Latinist and historian Jerzy Axer has stated, the Latin school drama in Poland-Lithuania was a unifying element for the political nation of the nobility; it was instrumental in safeguarding some of the common principles and virtues that kept Polish and Lithuanian nobles together. ${ }^{68}$

In 1648, Łukasz Opaliński (1612-66), one of the most prominent political writers in seventeenth-century Poland and marshal of the Polish diet, responded to an opinion expressed by a Scot, James Barclay, ${ }^{69}$ which he considered unfair:

67 Puchowski, “Jezuickie kolegium," 32-33.

68 Axer, "Polski teatr jezuicki jako teatr polityczny," 14, 21; see also, Axer, "Teatralne echa klęski pod Cecorą," Pamiętnik teatralny (1974): 71-82; "De vita aulica dialogus—Jezuicka przypowieść o służbie bożej i służbie królewskiej," Meander (1974): 179-86; Robert Aleksander Maryks, "'De vita aulica dialogus': L'inedito testo teatrale gesuitico del Codice di Uppsala R 380," AHSI 72 (2003): 323-404.

69 Barclay wrote that Poles "abhorre the very name, not only of slavery, but of obedience to a just and lawful Scepter. Their King by force of armes is compelled to observe their country lawes. The Nobility have bestowed upon themselves most mischievous prerogatives, by which they may safely abuse and hunt each other; because the King hath not Power 
It is true that we abhor slavery [...] and we love freedom. We conduct matters of state and take responsibility for our country not out of pressure or by orders, we do it because we enjoy and cherish our freedom. We do not know informers or spies - the kind of people invented to make the rest unhappy, we do not know severe punishment, prison, exile, or death without a cause - all this is unknown to us and we abhor it because ours is a free country and we have been blessed by God with freedom. ${ }^{70}$

This is the attitude that the Latin school drama of the Jesuits in PolandLithuania had to take into consideration when instructing their students. ${ }^{71}$ The cardinal virtues of prudence, courage, justice, and temperance were to be learned and practiced through drama to secure the divine gift of freedom for the nobility. The Jesuits arrived in a country where public disputations were at the heart of social and political life, whose most numerous estate adopted the rule of consent on all levels of local and national government. The practice of drama in Jesuit colleges adapted to the fashion of disputation among the Polish and Lithuanian nobility, as well as giving a new creative impulse for eloquence paired with virtue to enter the public sphere. In so doing, it helped members of the nobility develop a sense of responsibility, solidarity, and pride in their country's history.

enough to punish their offences in that kinde." John Barclay, Icon animorum or the Mirror of Minds, trans. Thomas May (1631), ed. Mark Riley (Ithaca, NY: Cornell University Press, 2013).

70 [Luca Opalinius], Polonia defensa contra Ioan. Barclaium: Vbi, occasione ista, de regno genteque Polona multa narrantur, hactenus litteris non tradita (1648), in Dla dobra Rzeczypospolitej: Antologia myśli państwowej, ed. Krzysztof Budziło et al. (Warsaw: Wydawnictwo Sejmowe, 1996), 88. Translation mine.

71 The cumulative number of playbills from those three congregations constitute a third of the Jesuit playbills from Poland-Lithuania. 